\begin{tabular}{l}
\multicolumn{1}{c}{ Kunnallisessa } \\
omistuksessako \\
kansanopistojen \\
pelastus? \\
Ajauduttuaan lähes \\
taloudelliseen \\
umpikujaan \\
Pohjois-Karjalan \\
Opisto siirtyi \\
vuoden 1991 \\
alussa Pohjois- \\
Karjalan \\
ammatillisten \\
oppilaitosten \\
kuntainliiton - \\
nykyisen koulutus- \\
kuntayhtymän - \\
omistukseen. \\
Onko tämä \\
mallina muillekin \\
taloudellisissa \\
vaikeuksissa \\
kamppaileville \\
opistoille?
\end{tabular}

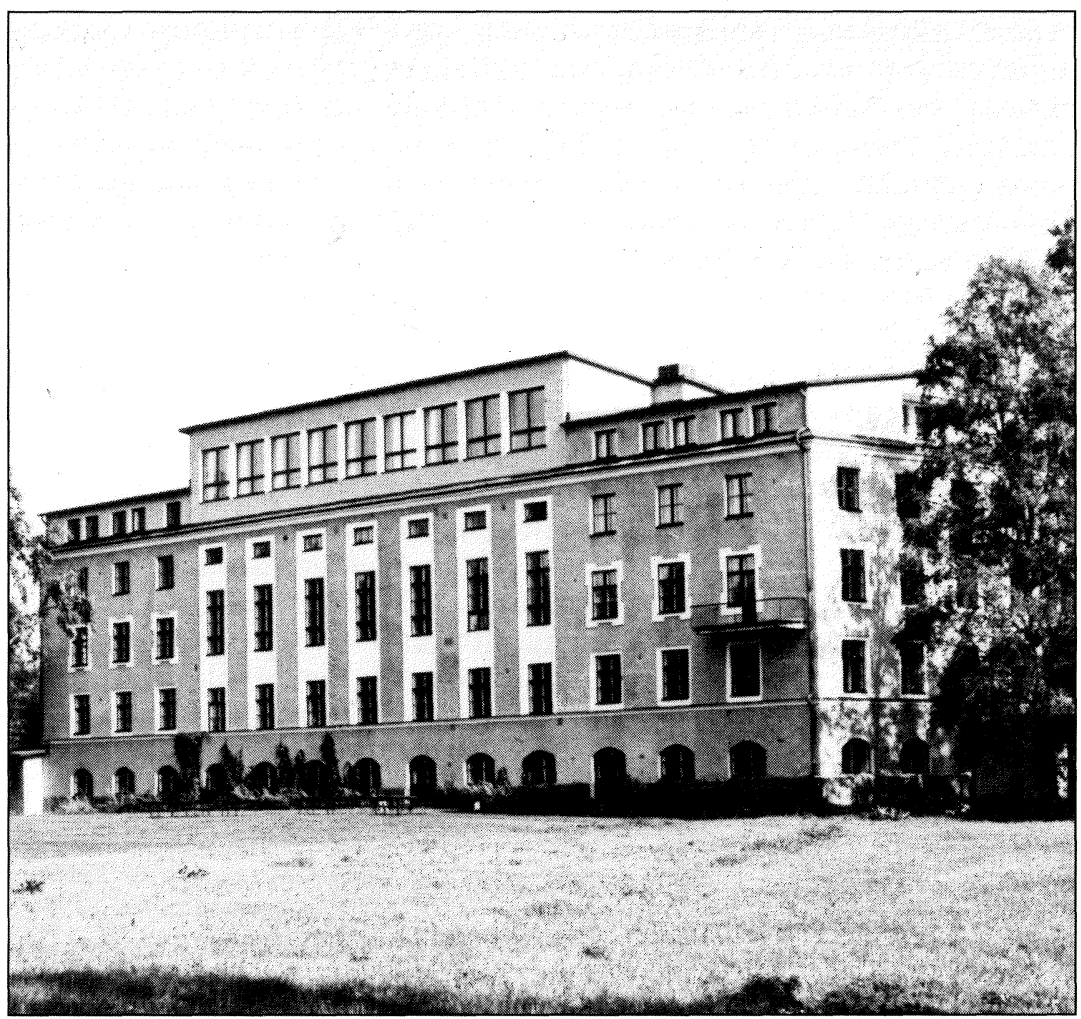

\title{
Kunnatko kansanopistoja pelastamaan?
}

Pyhäselän kunnassa Niittylahdessa sijaitseva Pohjois-Karjalan Opisto täyttää parin vuoden kuluttua sata vuotta. Parhaillaan laadinnanalaisena olevan historiikin mukaan opiston talous ei koskaan näytä olleen hurrattavassa kunnossa. Suuria kriisejä on ollut silloin tällöin, mm. silloin kun opiston päärakennus tuhoutui tulipalossa vuonna 1926.

Opiston hallinnosta vastaavat ovat ilmeisesti olleet - vaikka opisto ei toimikaan kristillisellä pohjalla - oikeita ihmeiden tekijöitä, sillä jollakin konstilla noista vaikeuksista on aina selvitty. 1980-luvun lopulla näytti pää kuitenkin tulevan vetävän käteen: vanhaa päärakennusta oli ollut pakko kunnostaa velkavaroin, ja kun sitten samoihin aikoihin opiskelijamäärä jäikin odotettua pienemmäksi, ei opiston omistava osakeyhtiö ollut enää selvitä Pyhäselän kunnan mukaantulosta huolimatta sitoumuksistaan. Monien vaiheiden jälkeen opiston pelastajaksi tuli Pohjois-Karjalan ammatillisten oppilaitosten kuntainliitto, jolla oli entuudestaan Pohjois-Karjalan alueella omistuksessaan suuri aikuiskoulutuskeskus ja viisi muuta ammatillista oppilaitosta. 
Mitkä lienevät olleet suurkuntainliiton motiivit opiston pelastusoperaatioon ryhdyttäessä? Koska en ollut vielä silloin opiston enkä kuntainliiton toiminnoissa mukana, voin vain arvailla niitä, sillä asiapapereista tällaisiin kysymyksiin on vaikea saada selkeää ja yksiselitteistä vastausta. Uskon, että se työ, mitä PohjoisKarjalan Opisto lähes sadan vuoden aikana on alueellaan tehnyt, on koettu arvokkaaksi. Ei kuitenkaan vain tähän saakka tehty työ, vaan opistolla nähdään edelleen olevan tärkeä tehtävä kansansivistyksen kohottajana. Ei haluttu tärkeänä vaikuttajana koetun opiston kaatuvan verraten pienten velkojen alle.

Toisena vaikuttimena saattoi olla kuntainliiton halu laajentaa vaikutusaluettaan läänin alueella pelkän ammatillisen koulutuksen ulkopuolelle. Merkityksetön ei varmaan ollut myös se seikka, että opistolle vuosien varrella kertynyt omaisuus ylitti monin kerroin velat - olkoonkin, että omaisuutta ei olisi helppo muuttaa käteiseksi rahaksi.

\section{Messiaan odotus}

Inhimillisessä elämässä näyttää vallitsevan yhteisön koosta riippumatta yllättävän paljon samankaltaisuuksia. Niinpä mm. silloin, kun yhteisö ajautuu sellaiseen kriisiin, josta on vaikea nähdä poispääsyä, yhtenä käyttäytymismuotona on aika yleisesti "Messiaan odotus". Odotetaan, että tulee jokin suuri voima, joka kuin ihmeen kautta poistaa kaikki yhteisön ongelmat. Tällaisesta käyttäytymisestä käynee hyvänä esimerkkinä itäisen naapurimaamme viimeaikaiset tapahtumat.

Samanlainen ilmiö taisi olla kyseessä myös silloin, kun Pohjois-Karjalan Opisto siirtyi kuntainliiton hallintaan. Uuteen omistajaan kohdistuvilla odotuksilla ei näytä olleen minkäänlaista rajaa: rahanpuute loppuu, opisto saa tarvitsemansa kymmeniä miljoonia maksavat lisärakennukset, kalusto pannaan hetkessä ajan tasalle, uusia kannattavia kursseja tipahtaa opiston syliin jne. jne. Kun nyt on kulunut kaksi vuotta hallinnon siirrosta, voi jo hiukan arvioida, ovatko nämä odotukset yleensä ja jos, niin missä määrin toteutuneet.

\section{Taloudellinen helpotus}

Käytännön työssä tuntuvin helpotus oli opiston maksuvalmiuden korjaantuminen. Laskut on voitu maksaa ajallaan ja näin ollen myös opiston luotettavuus kauppakumppanina - ja sitä kautta myös opiskelupaikkana on lisääntynyt. Opiston taloudenhoito on luotettavissa käsissä ja tämä luo turvallisuutta niin hyvin opiston sisällä kuin sen ulkopuolellakin.

Kunnallisen toiminnan luoteeseen kuuluu suunnitelmallisuus. Niinpä myös opiston toiminnassa on päästy kädestä suuhun elämisestä ja sekä toiminnan että talouden osalta asiat suunnitellaan ensin ja toteutetaan sitten, kun asianmukaiset päätökset on tehty. Tämä on tietysti lisännyt jonkin verran byrokratiaa, mutta on tuonut mukanaan myös lisää harkintaa.

\section{Rakennukset kuntoon}

Pohjois-Karjalan Opisto on kohta satavuotias. Vaikka sen rakennukset eivät ole vielä aivan yhtä vanhoja, on niissä kaiken aikaa paljon korjaamista. Varojen puutteessa säännöllinen huolto oli osin jouduttu jättämään tekemättä. Niinpä esimerkiksi opiston rantasauna oli rappeutunut käyttökelvottomaan kuntoon. Kunnalliseen hallintokäytäntöön liittyy kirjoittamaton velvoite laatia kiinteistön huollosta sekä pitkän aikavälin että vuosittain toteutettavaksi laadittu suunnitelma. Tätä toteutetaan sitten vuosittain sikäli, kun liittovaltuusto talousarvion vahvistamisen yhteydessä osoittaa tarkoitukseen varoja.

Jo näiden parin vuoden kuluessa opisto on alkanut puhdistaa kasvojaan. Lahoavia hökkeleitä on pihapiiristä kokonaan purettu, rantasauna on kunnostettu käyttökuntoon (tervetuloa; sitä vuokrataan kohtuuhinnalla) ja opiston asuntoja on pikkuhiljaa remontoitu. Näin ollen omistajanvaihdos näkyy selvästi ainakin fyysisissä puitteissa.

\section{Välineet ajanmukaisiksi}

Korjaustoiminnan lisäksi on kuntainliitto suonut mahdollisuuden myös opetusvälineistön ja 
kaluston uusintoihin. Niinpä jo nyt - kahden vuoden kuluttua omistajan vaihdoksesta - opistossa on sen kielten opetuksen vuoksi välttämätön kielistudio (viimeistä huutoa!), av-välineet ja muut opetustarvikkeet ovat ajanmukaisia eikä huonekaluistakaan enää mene tikku opiskelijan pyllyyn, kuten aikaisemmin aivan konkreettisesti saattoi käydä. Samoin opiston keittiö on ajanmukaistunut ja ruokasaliin on saatu kunnollinen tarjoilulinja.

\section{Henkiset arvot}

Edellä on kuvattu niitä suoraan havainnoitavia fyysisiä muutoksia, joita opiston kunnallistamiseen on liittynyt. Paljon vaikeampi on arvioida muutoksen henkistä puolta.

Pohjois-Karjalan koulutuskuntayhtymässä on monenlaisia oppilaitoksia. Niiden toimintaa suunnitellaan ja tarkastellaan yhdessä kuntayhtymän hallintoelimissä, erityisesti johtoryhmässä ja liittohallituksessa. Tässä kentässä opisto voi olla sekä saavana että antavana osapuolena. Yhtenä kansanopistojen ongelmana on niiden erillään olo ja siitä seurauksena usein eristyneisyys muusta koulujärjestelmästä. Kun samassa organisaatiossa on myös muita oppilaitoksia, tästä voi parhaimmillaan seurata hedelmällinen vuorovaikutus ja poispääsy sisäänlämpiävyydestä.

Koulutusvastuu lankeaa Suomessa pääasiassa kuntien tehtäväksi. Kunnan velvollisuuksiin kuuluu myös luoda kuntalaisille mahdollisuuksia hankkia tarvitsemaansa koulutusta. Silloin kun kansanopisto on osa kunnallista koulutusjärjestelmää, opiston niveltäminen siihen ja markkinointi osana kunnan toimintaa on luontevaa.

\section{Pelot}

Paitsi suuria odotuksia, liittyi opiston kunnallistamiseen myös pelkoja. Suurin näistä varmaan oli pelko vapauden menettämisestä. Vapaushan on kansanopistoille koko toiminnan perusta, oleellinen osa toiminta-ajatusta. Toinen pelko oli byrokratian lisääntyminen. Jouduttaessa kunnalliseen järjestellään tulisi vastaan valtion vaatiman byrokratian lisäksi myös kunnallinen byrokratia. Toteutuivatko pelot?

\section{"Vapaus on välttämättömyyden tajuamista"}

Opetushallituksen pääjohtaja Vilho Hirvi on todennut, että todellista vapautta on välttämättömyyden tajuaminen. Jokaisen ihmisen ja kaikkien organisaatioiden toiminta on yhteydessä muuhun maailmaan ja sen täytyy sopeutua siihen voidakseen olla olemassa.

Kansanopisto ei muodosta tässä suhteessa mitään poikkeusta. Ilman yhteyttä kulttuurielämään, koululaitokseen, valtioon, toiminnan kustantajiin tai opiskelijoihin ei tietenkään voi olla opistoakaan. Miten hyvin opisto osaa toimintaa suunnitellessaan ja järjestäessään ottaa nämä yhteydet huomioon, siitä riippuu opiston elämisen mahdollisuudet. Näin yksinkertaisesti vapauden voi määritellä. Kuntayhtymä omistajana on yksi osatekijä ja vaikuttaa opiston toimintaan. Ainakaan toistaiseksi se ei kuitenkaan ole kajonnut ns. pedagogiseen vapauteen, mutta on luonnollista, että opiston johtokunta - joka on osa kunnallista hallintoa - on päättämässä mm. opiston linjoista, kursseista, maksuista jne.

Entä byrokratia? Julkiseen hallintoon liittyy sellainen näkökohta, että kaiken toiminnan on oltava julkista ja näin ollen myös yhteiskunnan kontrolloitavissa. Tästä seuraa monenlaista, $\mathrm{mm}$. se, että asiat pitää dokumentoida. Ne on laitettava muotoon, jossa esimerkiksi tilintarkastajat voivat halutessaan myös jälkeenpäin arvioida tapahtuneen lainmukaisuutta ja myös tarkoituksenmukaisuutta. Joillekin tämä vaatimus on kauhistuttava. Toisille se luonnollista ja kuuluu osana rationaaliseen toimintaan.

Kunnallinen paperityö omine kaavoineen voi poiketa yksityisen osakeyhtiön vaatimasta paperisodasta, mutta koska sitäkin on koskenut tietyt säännöt, ei muutos ole ollut merkittävä. Joka tapauksessa kunnallinen byrokratia on vähäisempää kuin valtion edellyttämä ja kun sitäkin ollaan kaiken aikaa järkeistämässä, ei byrokratiasta kannata ottaa turhan suuria murheita. Välttämättömyydet on tietenkin hoidettava.

Joiltain osin muutos on ollut jopa myönteistä. Esimerkiksi koulutukseen lähtevä henkilön on 
turvallista jo lähtiessään aivan paperilla nähdä, kuinka hänelle aiheutuvat kustannukset korvataan.

\section{Toteutumattomat unelmat}

Kaikki omistajanvaihdokseen liittyvät odotukset ja pelot eivät toki ole toteutuneet. Opisto ei ole saanut eikä taida saadakaan uutta opiskelija-asuntolaa. Liikuntatilat ovat kyllä kuntayhtymän investointisuunnitelmissa, mutta taloudellisen tilanteen johdosta hyvin epävarmoissa asemissa. Raha ei kasva puussa, vaikka omistajana onkin kunnallinen yhteisö. Päinvastoin, joskus vaikuttaa siltä, että päättäjä pitää kukkaron nyörejä aivan kohtuuttoman tiukalla ja käyttötalousmenoissa on joka penni venytettävä vähintään yhtä soikeaksi kuin ennenkin. Kunnallinen säästövelvoite on pakottanut jättämään avoimeksi tulleita virkoja ja toimia täyttämättä. Myöskään opiston kurssitoimintaan ei omistaja ole pystynyt vaikuttamaan mitenkään. Jos siinä jotain aiotaan saatavan aikaan, niin aktiivisuuden on lähdettävä edelleenkin opiston omista työntekijöistä.
Samoin kuin odotukset niin myös pelot olivat liioiteltuja: vapaus ei mennyt eikä byrokratia kasvanut ylivoimaiseksi.

\section{Kunnissako opistojen pelastus?}

Kahden vuoden kokemuksen perusteella Pohjois-Karjalan Opiston siirtyminen osakeyhtiöltä kuntayhtymän omistukseen on kaikkien osapuolien osalta ollut myönteinen. Opisto on päässyt mukaan turvalliseen (jos nyt nykyaikana mikään on erityisen turvallista) yhteisöön. Omistajakunnille ei opistosta puolestaan ole aiheutunut kohtuuttomia kustannuksia ja opiskelijat ovat saaneet hyviä eteenpäinpääsyn mahdollisuuksia, ilman että se muihin koulumuotoihin verrattuna maksaisi kunnille paljoakaan.

Mikään patenttiratkaisu ei opistojen kunnallistaminen varmaankaan ole. Osa opistoista on taustayhteisöjensä aatteellisuuden vuoksi sangen kaukana kunnan toiminta-ajatuksesta, eikä varmaan haluaisikaan uutta omistajaa. Kaikkialla eivät vastaavasti kunnat ole valmiita laajentamaan toimintaansa kansanopistoja koskevaksi.


Sa numeroissaan keskustelua vapana sivistystyoun asernasta ja: tulevaisur. diesta: 